\title{
Pengembangan E-Learning Materi Fluida Dinamis Untuk Mengembangkan Keterampilan Berpikir Kreatif Siswa Sekolah Menengah Atas
}

\author{
Hana Aliyah Azhary, Ketang Wiyono* \\ Program Studi Pendidikan Fisika, Universitas Sriwijaya \\ *Email : ketangw.fkipunsri@gmail.com
}

Received: 12 Desember 2019;

Accepted: 3 Februari 2020;

Published: 6 Februari 2020

DOI: http://dx.doi.org/10.29303/jpft.v6i1.1541

\begin{abstract}
Succesfully conducted a study entitled development of e-learning on the subject of dynamic fluid to develop student's creative thinking skill in senior high school. This research is aimed at generating e-learning on the subject of dynamic fluid valid and practical. This study is a Research and Development $(R \& D)$ using Rowntree model which in the procedure consisted of three stages: planning stage, development stage and evaluation stage. The evaluation stage employed were formative evaluation Tessmer which consisted of four stages: self evaluation, expert review, one-to-one evaluation, and small group evaluation. The data collection technique using walkthrough and questionnaires. The validity is assessed by three experts that is in content aspect, learning design aspect, and e-learning aspect. Of the results expert review obtained an average assessment of 93,73\% with a very valid criteria. While on stage one-to-one evaluation showed an average assessment of $89,67 \%$ with a very practical criteria. In the small group evaluation, the result is an average percentage of $92,91 \%$ with a very practical criteria. Based on the result that e-learning on the subject of dynamic fluid to developing student's creative thinking skill in senior high school which have been developed into the criteria of very valid and very practical.
\end{abstract}

Keywords: e-learning; $21^{\text {st }}$ skills; creative thinking; schoology; dynamic fluid

\section{PENDAHULUAN}

Revolusi industri adalah sejarah perkembangan terpenting dalam kehidupan manusia selama tiga abad terakhir (Stearns, 2013). Perkembangan teknologi yang terjadi pada era revolusi industri mempengaruhi pola gaya hidup masyarakat global yang mendesak ketersediaan sumber daya manusia yang spesifik dan terampil (Puncreobutr, 2016). Perkembangan teknologi informasi dan komunikasi ini memberikan pengaruh dalam berbagai aspek kehidupan manusia, termasuk diantaranya dalam bidang pendidikan (Wiyono, 2013).

Dari berbagai kajian penelitian menyatakan bahwa pendidikan merupakan indikator kejayaan bangsa (Al Aslamiyah et al. 2019). Pendidikan adalah basis utama untuk berkontribusi ke semua sektor dengan menyediakan apa yang diperlukan baik keterampilan maupun pengetahuan (Anil,
2019). Perkembangan di bidang ICT memberikan pengaruh yang signifikan terhadap bagaimana proses pembelajaran fisika, khususnya pada efektivitas pembelajaran, efisiensi waktu dan fasilitas pendukung pembelajaran lainnya (Harjono et al. 2015). Mengingat perubahan teknologi ini, sektor pendidikan telah mengintegrasikan penerapan TIK dalam pendidikan yang menghasilkan pembentukan platform e-learning (Lee, 2010).

Dengan memasuki dunia online, pendidik dapat memperoleh berbagai informasi yang diperlukan untuk memenuhi kebutuhan pembelajaran (Herayanti et al. 2018). Pembelajaran online dapat dilakukan dengan menyediakan software LMS (Learning Management System) yang menyediakan fitur-fitur yang menunjang kegiatan pembelajaran (Herayanti et al. 
2015). E-learning adalah inovasi yang memiliki kontribusi besar terhadap perubahan proses pembelajaran (Rosy, 2018). Salah satu bagian dari e-learning adalah blended learning (pembelajaran campuran). Pembelajaran blended adalah suatu sistem pembelajaran yang mengkombinasikan sedemikian rupa antara strategi pembelajaran sinkron dan asinkron dalam rangka menciptakan pengalaman belajar untuk mencapai capaian pembelajaran yang telah ditentukan secara optimal (Chaeruman, 2017).

Blended learning tidak hanya menggabungkan pembelajaran tatap muka dengan pembelajaran online, tetapi juga menentukan strategi pembelajaran campuran yang paling tepat untuk mencapai serangkaian hasil belajar yang diinginkan (Chaeruman et al. 2018). Pembelajaran blended learning ditemukan efektif untuk mempelajari konsep teknologi pendidikan (Gambari et al. 2017). Sejalan dengan hal tersebut, pendekatan blended learning dapat diadopsi untuk melayani kebutuhan pelajar milenial (Wahab et al. 2018).

Trilling \& Fadel

(2009)

mengemukakan bahwa teknologi secara aktif melengkapi keterampilan belajar peserta didik pada abad ke-21. Pada abad ke21, kreativitas dan penggunaan teknologi adalah keterampilan yang sangat penting (Henriksen et al. 2016). Pengembangan kreativitas peserta didik merupakan bagian yang tidak terpisahkan dalam upaya peningkatan sumber daya manusia Indonesia (Yusro, 2017). Kreativitas muncul karena adanya semangat dalam perhatian terhadap kegiatan atau pekerjaan yang sedang dilakukan, adanya kelancaran pemikiran dalam menghasilkan berbagai ide cemerlang, adanya kemampuan untuk mengeksperimen dengan melakukan pengujian-pengujian sehingga dapat menemukan sesuatu yang bermanfaat (Sahidu et al, 2018).

Berpikir kreatif melibatkan identifikasi masalah, menemukan solusi, mengevaluasinya, dan mengkomunikasikan hasil (Ayob et al. 2013). Bahkan, lingkungan belajar yang kreatif mempengaruhi prestasi akademik, motivasi, keterlibatan, dan keterampilan berpikir (Davies, dkk., 2013). Oleh karena itu, diperlukan inovasi pembelajaran untuk membuat siswa lebih kreatif (Gunawan et al. 2018). Salah satu upaya untuk mengembangkan dan meningkatkan kreativitas adalah melalui pembelajaran berbasis komputer (Gunawan et al. 2018).

Sejak tahun 2006, tingkat penggunaan internet di sekolah sekitar 20\%, dapat diartikan bahwa sebanyak 20\% sekolah memiliki kesempatan memanfaatkan teknologi informasi dan komunikasi untuk permbelajaran (Prawiradilaga et al. 2013). Berdasarkan data survey IHS (Lucero, 2016), terdapat 23,14 milyar orang yang menggunakan alat elektronik berbasis internet pada tahun 2018 dan diperkirakan akan selalu meningkat hingga berkisar sekitar 75 milyar orang pada tahun 2025. Sehingga perlu adanya pemanfaatan yang signifikan di bidang pendidikan pada abad 21, yakni pengembangan e-learning pada sekolah menengah.

Berdasarkan survei kebutuhan, dengan jumlah responden 60 siswa yang tersebar ke dalam 15 sekolah yang ada di Sumatera Selatan maupun di luar Sumatera Selatan diperoleh data sebesar 45,2\% siswa hanya tahu apa itu e-learning. Sebesar $40,3 \%$ e-learning jarang diterapkan disekolah dan bahkan $48,4 \%$ siswa menyatakan bahwa e-learning belum pernah sama sekali diterapkan disekolah. Padahal dalam pendidikan saat ini, akses informasi tidak terbatas ruang dan waktu serta proses 
belajar mengajar telah menjadi dinamis (Halili, 2019).

Peneliti menyadari dengan data tersebut penting dikembangkannya $e$ learning sebagai inovasi pembelajaran melalui internet yang dapat diakses secara mudah, kapan saja dan dimana saja. Sejalan dengan hal tersebut, berdasarkan data survey kebutuhan diperoleh data sebesar 96,8\% siswa menyatakan bahwa perlu dan pentingnya pengembangan e-learning pada pembelajaran fisika di sekolah.

\section{METODE PENELITIAN}

Dalam penelitian e-learning materi fluida dinamis ini, metode yang digunakan adalah penelitian pengembangan (development research) dengan model pengembangan Rowntree yang memiliki tiga tahap pelaksanaan yaitu tahap perencanaan, tahap pengembangan dan tahap evaluasi (Prawiradilaga, 2007).

Pada tahap perencanaan terbagi ke dalam beberapa sub-tahap yaitu analisis kebutuhan dan perumusan tujuan pembelajaran. Tahap pengembangan terbagi menjadi beberapa sub-tahap yaitu pengembangan topik, penyusunan draf, produksi prototipe dari produk yang akan digunakan untuk pembelajaran. Tahap evaluasi, peneliti menggunakan model evaluasi formatif Tessmer yang terdiri dari empat tahap yaitu: (1) self evaluation, (2) expert review, (3) one-to-one evaluation, dan (4) small group evaluation.

Penelitian ini dilakukan pada semester ganjil-genap tahun ajaran 2019/2020 di SMA Negeri 1 Unggulan Indralaya Utara. Penelitian ini dilakukan untuk mengembangkan keterampilan berpikir kreatif siswa sekolah menengah atas yang mengacu pada indikator berpikir kreatif, yaitu (1) Mampu mengunakan berbagai cara untuk menghasilkan ide misalnya melalui curah pendapat (diskusi);
(2) Membuat ide-ide baru dan menambahkan ide; (3) Mengelaborasi, memperbaiki, menganalisa, dan mengevaluasi ide-ide orisinal untuk meningkatkan dan memaksimalkan usaha (Mahanal, 2014).

Teknik pengumpulan data yang digunakan adalah teknik walkthrough dan angket. Lembar validasi yang diberikan berupa bentuk skala likert yang dibuat dalam bentuk tabel checklist dengan lima kategori jawaban seperti Tabel 1.

Tabel 1. Kategori Nilai Validasi

\begin{tabular}{cc}
\hline Kategori Jawaban & Skor Pernyataan \\
\hline Sangat sesuai & 5 \\
Sesuai & 4 \\
Cukup sesuai & 3 \\
Kurang sesuai & 2 \\
Tidak sesuai & 1
\end{tabular}

Sumber: (Sugiyono, 2016)

Kemudian dicari persentase hasil validasi ahli (HVA) dari indikator validasi yang berpedoman pada Wiyono (2015) dengan rumus:

$$
\text { HVA }=\frac{\text { jumlah skor keseluruhan tiap indikator }}{\text { keseluruhan skor maksimal }} \times 100 \%
$$

Persentase hasil analisis walkthrough menyatakan tingkat kevalidan dari $e$ learning, sebagaimana mengacu pada Tabel 2.

Tabel 2. Kategori Hasil Validasi Ahli

$\begin{array}{cc}\text { Persentase \% } & \text { Kategori } \\ 86 \leq \mathrm{HVA} \leq 100 & \text { Sangat valid } \\ 70 \leq \mathrm{HVA}<86 & \text { Valid } \\ 56 \leq \mathrm{HVA}<70 & \text { Kurang valid } \\ \text { HVA }<56 & \text { Tidak valid }\end{array}$

Sedangkan, nilai angket yang diberikan berbentuk skala likert yang dibuat dalam bentuk tabel checklist dengan lima kategori jawaban seperti pada Tabel 3.

Tabel 3. Kategori Nilai Angket 


\begin{tabular}{cc}
\hline Kategori Jawaban & Skor Pernyataan \\
\hline Sangat sesuai & 5 \\
Sesuai & 4 \\
Cukup sesuai & 3 \\
Kurang sesuai & 2 \\
Tidak sesuai & 1
\end{tabular}

Sumber: (Sugiyono, 2016)

Kemudian dicari persentase hasil one to one evaluation dan small group (HEOS) yang berpedoman pada Wiyono (2015) dengan rumus:

$$
\text { HEOS }=\frac{\text { Skor raihan angket }}{\text { Skor maksimal angket }} \times 100 \%
$$

Persentase HEOS ini kemudian dicocokkan dengan tabel kategori hasil nilai angket yang disajikan pada Tabel 4 .

Tabel 4. Kategori Hasil Nilai Angket

\begin{tabular}{cc}
\hline Persentase \% & Kategori \\
\hline $86 \leq H E O S \leq 100$ & Sangat praktis \\
$70 \leq H E O S<86$ & Praktis \\
$56 \leq H E O S<70$ & Kurang praktis \\
HEOS $<56$ & Tidak praktis \\
\hline
\end{tabular}

Sumber: (Wiyono, 2015)

\section{HASIL DAN PEMBAHASAN}

Penelitian ini dilakukan dengan tiga tahap yaitu tahap perencanaan, tahap pengembangan, dan tahap evaluasi. Pada tahap evaluasi, peneliti menggunakan tahap evaluasi Tessmer yang terdiri dari empat tahap, yaitu self evaluation, expert review, one-to-one evaluation, dan small group evaluation. Pada tahap perencanaan dilakukan analisis kebutuhan dan perumusan tujuan pembelajaran. Pada analisis kebutuhan dilakukan analisis pembelajaran pada abad 21, analisis peserta didik, dan analisis materi.

Sejak munculnya gerakan global yang menyerukan model pembelajaran baru untuk abad ke-21, perubahan sistem pembelajaran pun bermunculan untuk mengatasi tantangan global yang kompleks. Identifikasi kompetensi siswa yang perlu dikembangkan merupakan hal yang sangat penting untuk menghadapi abad ke-21. Siswa diharapkan tidak lagi berfokus untuk berhasil dalam melakukan pekerjaanpekerjaan manual atau pekerjaan rutin berbantuan mesin.

Saat ini, indikator keberhasilan lebih didasarkan pada kemampuan untuk berkomunikasi, berbagi, dan menggunakan informasi untuk memecahkan masalah yang kompleks, dapat beradaptasi dan berinovasi. Standar baru diperlukan agar siswa kelak memiliki kompetensi yang diperlukan pada abad ke-21. Sekolah ditantang menemukan cara dalam rangka memungkinkan siswa sukses dalam pekerjaan dan kehidupan melalui penguasaan keterampilan berpikir kreatif, pemecahan masalah yang fleksibel, berkolaborasi dan berinovasi.

Dalam analisis kebutuhan dilakukan penyebaran angket dan diperoleh responden sebanyak 60 siswa SMA yang tersebar dalam 15 sekolah baik di Sumatera Selatan maupun di luar Sumatera Selatan. Hasil angket menunjukkan bahwa sebesar $45,2 \%$ siswa hanya tahu apa itu e-learning, sebesar $11,3 \%$ siswa yang terbiasa mengaplikasikan e-learning disekolah, lalu 40,3\% e-learning jarang diterapkan disekolah. Bahkan 48,4\% siswa menyatakan bahwa e-learning belum pernah sama sekali diterapkan disekolah. Padahal sejak tahun 2006, tingkat penggunaan internet di sekolah sekitar 20\%, dapat diartikan bahwa sebanyak $20 \%$ sekolah memiliki kesempatan memanfaatkan teknologi informasi dan komunikasi untuk permbelajaran (Prawiradilaga., dkk, 2013).

Selanjutnya dilakukan wawancara dengan seorang guru fisika di SMAN 1 Unggulan Indralaya Utara tempat dimana penelitian ini berlangsung. Kegiatan ini dilakukan untuk mengetahui kendala/masalah yang terjadi dalam proses pembelajaran. Hasil wawancara menunjukkan bahwa di SMAN 1 Unggulan 
Indralaya Utara selain menjadi sekolah yang mengadakan kelas digital dalam proses pembelajarannya, namun di SMAN 1 Indralaya Utara belum mengintegrasikan semua materi pembelajaran khususnya fisika dalam bentuk pembelajaran elektronik.

Selain membosankan dan beberapa materi yang bersifat abstrak pada penguasaan konsep perlu adanya keterampilan berpikir pada peserta didik. Dapat dilihat dari kompetensi dasar materi fluida dinamis telah mengacu pada keterampilan abad 21, yakni (1) menerapkan prinsip fluida dinamis dalam teknologi, (2) membuat dan menguji proyek sederhana yang menerapkan prinsip dinamika fluida.

Berdasarkan hasil angket diperoleh data sebesar 96,8\% siswa menyatakan bahwa perlu adanya pengembangan $e$ learning pada pembelajaran fisika, hal ini pun mendukung adanya penelitian pengembangan e-learning. E-learning diharapkan dapat membantu guru dalam menyampaikan materi fisika yang membosankan bagi siswa dimana sebagian besar materi dan konsep disajikan dalam bentuk rumus matematis yang rumit.

Pada tahap pengembangan diawali dengan melakukan pengembangan topik, penyusunan draft, dan produksi prototipe. Pada tahap pengembangan topik dimulai dengan penyusunan materi pembelajaran. Materi pembelajaran yang dikembangkan hendaknya sesuai dengan tujuan pembelajaran yang akan dicapai oleh peserta didik.

Tahap penyusunan draft dilakukan dengan membuat rancangan awal e-learning materi fluida dinamis dan dilanjutkan dengan membuat storyboard yang digunakan sebagai acuan dalam pengembangan $e$ learning. Rancangan awal dapat berupa flowchart yang mendeskripsikan menumenu atau fitur-fitur yang terdapat dalam $e$ learning yang dapat dilihat pada gambar 1 .

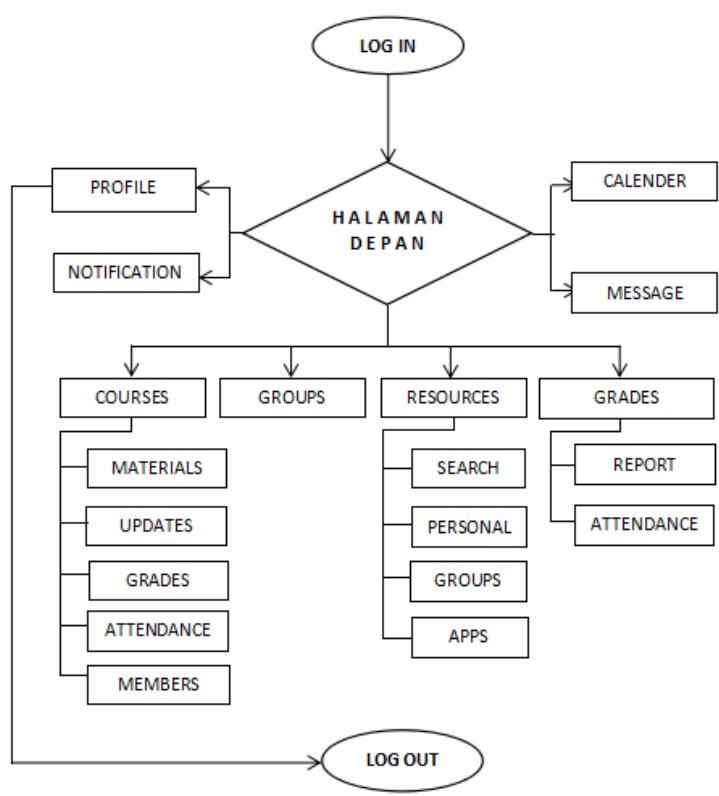

Gambar 1. Flowchart E-learning Materi Fluida Dinamis

Pada tahap produksi prototipe, $e$ learning materi fluida dinamis ini dikembangkan dengan menggunakan aplikasi schoology. Schoology merupakan learning management system (LMS) yang menyediakan layanan kepada pengguna untuk membuat, mengatur, dan membagikan file. Tampilan schoology hampir mirip dengan situs jejaring sosial facebook atau situs jejaring sosial lainnya. Schoology adalah alat pendidikan yang menjanjikan untuk memenuhi tantangan saat ini dan masa depan mengajar dan belajar di abad ke-21 (Biswas, 2018).

Schoology memiliki tiga pilihan pengguna untuk mengaksesnya, yaitu pengguna sebagai guru (teacher), siswa (student), dan orangtua (parent). Jadi, selain guru dan siswa yang dapat mengakses $e$ learning ini, orangtuapun dapat mengontrol anaknya dengan mengakses e-learning sebagai pengguna. Melalui schoology, kita bisa berinteraksi sosial sekaligus belajar. Adapun fitur-fitur yang dimiliki oleh schoology diantaranya adalah courses (kursus), yaitu fasilitas untuk membuat kelas mata pelajaran, misalnya mata pelajaran fisika, groups (kelompok) yaitu fasilitas 
untuk membuat kelompok, dan resources (sumber belajar).

Selain itu, karena fasilitas dalam schoology sangat mendukung penulisan teks, rumus, dan gambar, itu dapat memfasilitasi proses penilaian pada mata pelajaran fisika, dan siswa kehilangan kecemasan mereka dalam belajar fisika (Hilyana \& Hakim, 2018). Adapun tampilan awal dari schoology dapat dilihat pada Gambar 2.

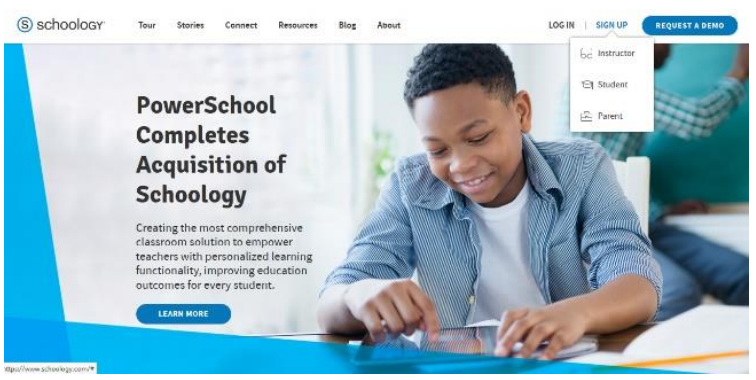

Gambar 2. Tampilan Awal Schoology

Sedangkan untuk screenshoot dari $e$ learning yang telah dikembangkan dengan menggunakan schoology dapat dilihat pada gambar 3, gambar 4, dan gambar 5.

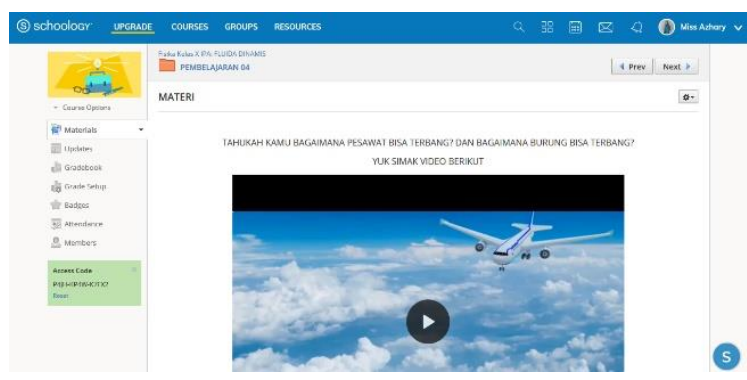

Gambar 3. Prototipe e-learning

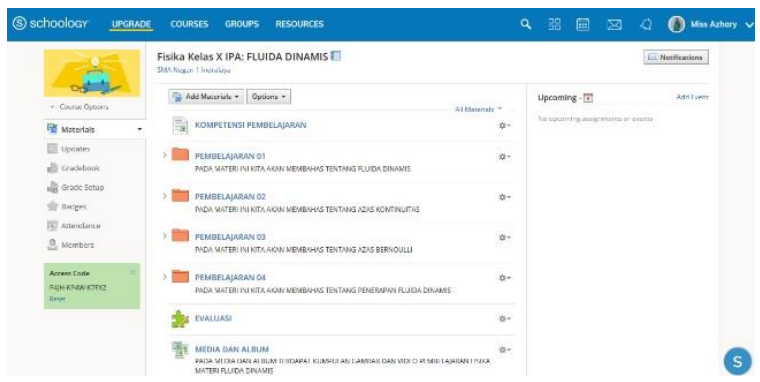

Gambar 4. Prototipe e-learning

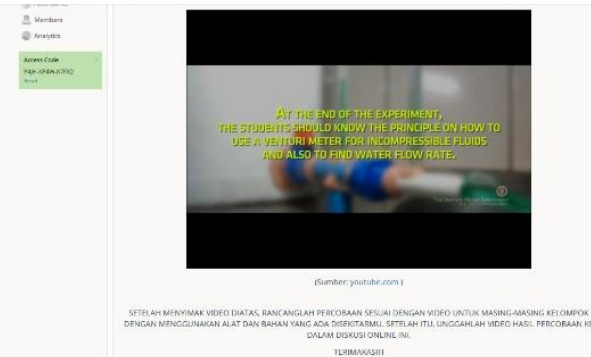

Gambar 5. Prototipe e-learning

Pemilihan schoology sebagai pembelajaran elektronik pun memiliki beberapa alasan, yaitu schoology menyediakan fitur yang lengkap mulai dari fitur untuk mencatat kehadiran siswa, raport online, ujian online, diskusi online, serta tugas atau kuis maupun PR. Pada e-learning schoology ini dapat diterapkan secara blended learning mengingat dengan pembelajaran tersebut dipercaya dapat menghilangkan kebosanan siswa dalam belajar.

Sejalan dengan hal tersebut, pendekatan blended learning dapat diadopsi untuk melayani kebutuhan pelajar milenial. Pembelajaran blended itu sendiri adalah pembelajaran yang menggabungkan model pembelajaran tradisional (tatap muka) dengan model pembelajaran online (elearning). Dengan kata lain, siswa yang telah melakukan aktivitas pembelajaran di kelas dapat mengulang kembali materi yang kurang dipahami dan belajar ulang di $e$ learning schoology.

Tahap pertama adalah self evaluation yang dimulai dengan menilai sendiri dan melakukan pengecekan terhadap produk yang dikembangkan yang dibimbing oleh dosen pembimbing skripsi. Produk berupa $e$ learning yang telah direvisi pada tahap self evaluation selanjutnya akan divalidasi oleh tiga validator pada tahap expert review. Tahap ini dilakukan untuk mengetahui tingkat kevalidan dari e-learning yang dibuat. Disini peneliti memohon bantuan kepada tiga ahli sebagai validator dalam aspek e-learning, aspek materi (content), 
dan aspek desain pembelajaran. Ketiga validator tersebut terdiri dari seorang dosen fakultas ilmu komputer UNSRI, serta dua dosen lain adalah dosen pendidikan fisika FKIP UNSRI.

Pada tahap expert review ini ketiga validator diberikan lembar angket masingmasing sesuai dengan aspeknya, yaitu aspek e-learning, aspek materi content), dan aspek desain pembelajaran. Lembar angket yang diberikan berbentuk skala likert yang dibuat dalam bentuk tabel checklist dengan lima kategori jawaban berdasarkan Sugiyono (2016) yang dapat dilihat pada Tabel 1. Kemudian dicari persentase hasil validasi ahli (HVA) dari indikator validasi yang berpedoman pada Wiyono (2015). Setelah dikalkulasikan, sesuaikan persentase hasil validasi dengan Tabel 2 tentang kategori hasil validasi ahli.

Adapun hasil validasi ahli terhadap e-learning materi fluida dinamis yang meliputi aspek materi, aspek desain pembelajaran, dan aspek e-learning dapat dilihat pada Tabel 5 .

Tabel 5. Hasil Penilaian Validator pada Tahap Expert Review

\begin{tabular}{cc}
\hline Validator Aspek & $\begin{array}{c}\text { Persentase } \\
(\boldsymbol{\%})\end{array}$ \\
\hline Aspek materi & 94,76 \\
\hline Aspek -learning & 86,43 \\
\hline Aspek desain pembelajaran & 100,00 \\
\hline Rata-rata & 93,73 \\
\hline
\end{tabular}

Perolehan rerata total skor validasi aspek materi sebesar $94,76 \%$ dan termasuk kategori sangat valid, skor validasi aspek $e$ learning sebesar $86,43 \%$ dan termasuk kategori sangat valid, serta validasi aspek desain pembelajaran sebesar $100 \%$ dan juga termasuk dalam kategori sangat valid. Sehingga, persentase rerata keseluruhan hasil penilaian validasi e-learning pada materi fluida dinamis yang diperoleh dari validator adalah sebesar $93,73 \%$ dan berdasarkan
Tabel 2 persentase ini termasuk kedalam kategori sangat valid dan layak untuk diujicobakan. Selain memberikan penilaian secara numerik, validator ahli pun memberikan komentar dan saran terkait $e$ learning yang dikembangkan sebagai bahan untuk perbaikan $e$-learning. Komentar yang pertama yaitu video lebih variatif. Pada schoology terdapat beberapa fitur yang dapat dijadikan wadah bagi siswa untuk mengembangkan keterampilan berpikir kreatifnya.

Selanjutnya yaitu tahap one-to-one evaluation, dimana validasi dilakukan oleh tiga orang siswa dari kelas XII IPA 1 SMAN 1 Unggulan Indralaya Utara. Ketiga orang siswa yang dipilih mewakili siswa yang tergolong kelompok tinggi, kelompok sedang, dan kelompok rendah yang disarankan oleh guru mata pelajaran fisika. Pada tahap ini, peneliti membimbing ketiga siswa tersebut dengan menjelaskan secara jelas mengenai fitur-fitur yang ada di schoology serta menjelaskan bagaimana cara pengoperasiannya.

Setelah itu, siswa tersebut diberikan angket terkait e-learning schoology yang berupa skala likert berbentuk tabel checklist dengan lima kategori jawaban berdasarkan Sugiyono (2016) yang dapat dilihat pada Tabel 3 tentang kategori nilai angket. Kemudian dicari persentase hasil one to one evaluation dan small group (HEOS) yang berpedoman pada Wiyono (2015). Setelah dikalkulasikan, sesuaikan persentase hasil validasi dengan Tabel 4 tentang kategori hasil nilai angket.

Berdasarkan data Tabel 4 tentang kategori hasil nilai angket, diperoleh hasil tanggapan siswa terhadap penggunaan $e$ learning materi fluida dinamis untuk mengembangkan keterampilan berpikir kreatif siswa SMA pada tahap one-to-one evaluation sebesar $89,67 \%$ sehingga dapat disimpulkan bahwa penggunaan e-learning 
materi fluida dinamis untuk mengembangkan keterampilan berpikir kreatif siswa SMA memiliki kriteria sangat praktis.

Tabel 6. Hasil Penilaian Angket Tahap One-toOne Evaluation

\begin{tabular}{cc}
\hline Nama Siswa & $\begin{array}{c}\text { Persentase } \\
(\mathbf{\%})\end{array}$ \\
\hline IIS & 90,20 \\
\hline KAA & 88,40 \\
\hline DDH & 90,40 \\
\hline Rata-rata & 89,67 \\
\hline
\end{tabular}

Tahap selanjutnya yaitu tahap uji coba small group evaluation yang dilakukan setelah dilakukannya revisi pada tahap expert review dan one-to-one evaluation. Pada tahap ini, peneliti memilih sembilan orang siswa dari kelas XI IPA 1 SMAN 1 Unggulan Indralaya Utara yang mencakup tiga siswa termasuk dalam kategori tinggi, tiga siswa termasuk kategori sedang, dan tiga siswa termasuk kategori rendah yang didasarkan atas saran dari guru mata pelajaran fisika.

Tabel 7. Hasil Penilaian Angket Tahap Small Group Evaluation

\begin{tabular}{lcc}
\hline No & Nama & Persentase (\%) \\
\hline 1. & MSA & 90,77 \\
\hline 2. & MR & 100,00 \\
\hline 3. & MA & 93,85 \\
\hline 4. & RPL & 87,69 \\
\hline 5. & AY & 93,85 \\
\hline 6. & WFP & 96,92 \\
\hline 7. & FA & 92,31 \\
\hline 8. & NOA & 83,08 \\
\hline 9. & CV & 87,69 \\
\hline $\begin{array}{l}\text { Rerata hasil pada tahap } \\
\text { smallgroup evaluation }\end{array}$ & 92,91 \\
\hline
\end{tabular}

Sebelum melaksanakan kegiatan pembelajaran, peneliti menjelaskan bagaimana pengoperasian e-learning schoology kepada siswa. Setelah itu, siswa melakukan pembelajaran yang kemudian diakhir pembelajaran diminta untuk mengisi lembar angket terkait e-learning schoology. Angket yang diberikan berupa skala likert berbentuk tabel checklist dengan lima kategori jawaban berdasarkan Sugiyono (2016) yang dapat dilihat pada Tabel 3 tentang kategori nilai angket. Kemudian dicari persentase hasil one to one evaluation dan small group evaluation (HEOS) yang berpedoman pada Wiyono (2015). Setelah dikalkulasikan, sesuaikan persentase hasil validasi dengan Tabel 4 tentang kategori hasil nilai angket.

Berdasarkan data pada Tabel 4 tentang kategori hasil nilai angket, dapat disimpulkan bahwa rerata keseluruhan penilaian angket tanggapan siswa pada tahap small group evaluation terhadap penggunaan e-learning adalah sebesar 92,91\% dan termasuk ke dalam kategori sangat praktis.

\section{PENUTUP}

Berdasarkan penelitian yang dilakukan bahwa pengembangan e-learning materi fluida dinamis untuk mengembangkan keterampilan berpikir kreatif siswa SMA telah sangat valid dan sangat praktis dengan perolehan data sebesar $93,73 \%$ untuk tahap expert review, sebesar $89,67 \%$ untuk tahap one-to-one evaluation, dan sebesar $92,91 \%$ untuk tahap small group evaluation. Dalam rangka meningkatkan kualitas pembelajaran di sekolah menengah atas, maka disarankan untuk perlu dikembangkan lagi e-learning materi yang berbeda, mengingat pembelajaran saat ini telah terintegrasi dengan teknologi. Hal ini didukung berdasarkan hasil survey kebutuhan sebesar 96,8\% siswa menyatakan bahwa perlu dan pentingnya pengembangan e-learning pada pembelajaran fisika di sekolah.

\section{REFERENSI}

Al Aslamiyah, T., Setyosari, P., \& Praherdhiono, H. (2019). Blended Learning dan Kemandirian Belajar Mahasiswa Teknologi Pendidikan. 
Jurnal Kajian Teknologi Pendidikan, 2(2), 109-114.

Anil, A. (2019). Education In The 21 st Century: The Dynamics of Change. The Research Journal of Social Sciences, 10(3), 128-133.

Ayob, A., Hussain, A., \& Majid, R. A. (2013). A Review of Research on Creative Teachers in Higher Education. International Education Studies, 6(6), 8-14.

https://doi.org/10.5539/ies.v6n6p8

Biswas, S. (2018). Schoology-Supported Classroom Management: A Curriculum Review. Northwest Journal of Teacher Education, 11(2), 187-196. https://doi.org/10.15760/nwjte.2013.11 .2 .12

Chaeruman, U. A. (2017). Pedati Model Desain Sistem Pembelajaran Blended. Jakarta: Direktorat Jenderal Pembelajaran dan Kemahasiswaan Kementrian Riset, Teknologi, dan Pendidikan Tinggi.

Chaeruman, U. A., Wibawa, B., \& Syahrial, Z. (2018). Determining the Appropriate Blend of Blended Learning: A Formative Research in the Context of Spada-Indonesia. American Journal of Educational Research, 6(3), 188-195. https://doi.org/10.12691/education-63-5

Davies, D., Jindal-Snape, D., Collier, C., Digby, R., Hay, P., \& Howe, A. (2013). Creative Learning Environments in Education-A Systematic Literature Review. Thinking Skills and Creativity, $8(1)$, 80-91. https://doi.org/10.1016/j.tsc.2012.07.0 04

Gambari, A. I., Shittu, A. T., Ogunlade, O. O., \& Osunlade, O. R. (2017). Effectiveness Of Blended Learning and E-learning Modes Of Instruction On The Performance Of Undergraduates In Kwara State, Nigeria. Malaysian Online Journal of Education Science, 5(1), 25-36. Retrieved from www.mojes.net
Gunawan., Harjono, A., Sahidu, H., \& Nisrina, N. (2018). Improving students' creativity using cooperative learning with virtual media on static fluida concept. Journal of Physics: Conference Series, 1006(1), 1-6.

Gunawan, G., Suranti, N. M.Y., Nisrina, N., Herayanti, L., \& Rahmatiah, R. (2018). The effect of virtual lab and gender toward students' creativity of physics in senior high school. Journal of Physics: Conference Series, 1108(1), 1-7.

Halili, S. H. (2019). Technological Advancements In Education 4.0. The Online Journal of Distance Education and E-Learning, 7(1), 63-69. Retrieved from www.tojdel.net

Harjono, A., Gunawan, \& Sutrio. (2015). Multimedia Interaktif dalam Pembelajaran Konsep Listrik Bagi Calon Guru. Jurnal Pendidikan Fisika dan Teknologi, 1(1), 9-14.

Henriksen, D., Mishra, P., \& Fisher, P. (2016). Infusing Creativity and Technology in 21st Century Education: A Systemic View for Change. Educational Technology \& Society, 19(3), 27-37. https://doi.org/10.1111/j.00330124.1966.00146.x

Herayanti, L., Fuaddunnazmi, M., \& Habibi. (2015). Pengembangan Media Pembelajaran Berbasis Moodle Pada Mata Kuliah Fisika Dasar. Jurnal Pendidikan Fisika Dan Teknologi, 1(3), 205-209.

Herayanti, L., Gummah, S., Sukroyanti, B. A., Gunawan, \& Makhrus, M. (2018). Pengembangan Perangkat Pembelajaran Berbasis Masalah Menggunakan Media Moodle Untuk Meningkatkan Keterampilan Berpikir Kritis Mahasiswa Pada Materi Gelombang. Jurnal Pendidikan Fisika Dan Teknologi, 4(2), 158-167.

Hilyana, F. S., \& Hakim, M. M. (2018). Integrating Character Education On 
Physics Course With Schoology Based E-learning. Journal of Information Technology Education: Research, 17(1), 577-593.

Lee, J. W. (2010). Online Support Service Quality, Online Learning Acceptance, and Student Satisfaction. Internet and Higher Education, 13(4), 277-283. https://doi.org/10.1016/j.iheduc.2010.0 8.002

Lucero, S. (2016). IoT platforms : Enabling The Internet of Things. (March).

Mahanal, S. (2014). Peran Guru dalam Melahirkan Generasi Emas dengan Keterampilan Abad 21. Seminar Nasional Pendidikan HMPS Pendidikan Biologi FKIP Universitas Halu Oleo, 1-16.

Prawiradilaga, D. S., Ariani, D., \& Handoko, H. (2013). Mozaik Teknologi Pendidikan E-Learning. Jakarta: Kencana Prenadamedia Group.

Puncreobutr, V. (2016). Education 4.0: New Challenge of Learning. Humanitarian and Socio-Economic Sciences, 2(2), 92-97.

Rosy, B. (2018). Schoology, Changing A Negative Thinking Pattern About Use of Social Media. IJIE (Indonesian Journal of Informatics Education), 2(1), 1-6. https://doi.org/10.20961/ijie.v2i1.2161 2

Sahidu, H., Gunawan., Rokhmat, J., \& Rahayu, S. (2018). Pengembangan Perangkat Pembelajaran Fisika Berorientasi Pada Kreativitas Calon Guru. Jurnal Pendidikan Fisika dan Teknologi, 4(1), 49-55.

Stearns, P. N. (2013). The Industrial Revolution in World History (4th ed). USA: Westview Press.

Sugiyono. (2016). Metode Penelitian \& Pengembangan Research and Development. Bandung: Alfabeta.

Trilling, B., \& Fadel, C. (2009). 21st Century Skills: Learning For Life in
Our Times. San Francisco: JosseyBass.

Wahab, N. A., Zain, A. M., \& Yunus, M. M. (2018). Exploring The Blended Learning Experience Among 21ST Century Language Learners. Journal of Language and Communication, 5(1), 136-149.

Wiyono, K. (2013). Pengembangan Model Pembelajaran Fisika Berbasis ICT Pada Implementasi Kurikulum 2013. Jurnal Inovasi Dan Pembelajaran Fisika, 2(2), 123-131.

Wiyono, K. (2015). Pengembangan model pembelajaran fisika berbasis ICT pada implementasi kurikulum 2013. Jurnal Inovasi dan Pembelajaran Fisika, 2(2), 123-131.

Yusro, A. C. (2017). Pengembangan Perangkat Pembelajaran Fisika Berbasis SETS Untuk Meningkatkan Kemampuan Berpikir Kreatif Siswa. Jurnal Pendidikan Fisika Dan Keilmuan (JPFK), 1(2), 61-66. https://doi.org/10.25273/jpfk.v1i2.13. 